\title{
THE RULE OF LAW OR THE PERCEPTION OF THE BEHOLDER? WHY INVESTMENT ARBITRATORS ARE UNDER FIRE AND TRADE ADJUDICATORS ARE NOT: A RESPONSE TO JOOST PAUWELYN
}

\author{
Freya Baetens*
}

In his thought-provoking and timely article, Pauwelyn asks how it can be "that today's perception of two parallel processes involving the legalization of world politics, and on two closely related subjects of global economic affairs - cross-border trade and cross-border investment—differs so much?"1 He focuses on one explanation: the individuals deciding World Trade Organization (WTO) versus International Centre for the Settlement of Investment Disputes (ICSID) disputes.

\section{Comparing Regimes or Perceptions of Regimes?}

Pauwelyn identifies five factors accounting for the differences in perception between WTO and ICSID dispute settlement-but their significance can be disputed. (1) Substantive investment rules are often perceived as limiting the right to regulate (while there is no empirical proof that they actually do so) but so are WTO rules (environmental measures protecting endangered species, prohibiting hormones and GMOs, etc.). (2) InvestorState Dispute Settlement (ISDS) is often perceived as biased in favor of multinational companies (although many claims are brought by small and medium-sized enterprises) ${ }^{2}$ but WTO dispute settlement is equally often seen as biased in favor of developed members (pushed by some multinational corporate lobby). (3) In spite of some rare high profile cases, very few ISDS claims are brought against public laws and regulations: the overwhelming majority concerns administrative or executive decisions affecting a particular investor. ${ }^{3}$ In the few cases where legislation was challenged, the investor almost invariably loses. ${ }^{4}$ This is different from the WTO disputes where most claims are brought against public laws and regulations. (4) Undoubtedly, the realization that developed countries can be sued under the ISDS system has caused a "shock effect"- - but does this differ from the reaction to the first cases against developed WTO Members? (5) Both investment protection standards and trade

* Associate Professor of Law (Faculty of Law) and Director of the LUC Research Centre (Faculty of Governance and Global Affairs) at Leiden University and Visiting Professor at the National University Singapore (NUS).

Originally published online 13 April 2016.

1 Joost Pauwelyn, The Rule of Law Without the Rule of Lanyers? Why Investment Arbitrators are from Mars, Trade Adjudicators from Venus, 109 AJIL 761, 761 (2015).

2 Organisation for Economic Co-operation and Development, Investment Division, Directorate for Financial and Enterprise Affairs, Investor-Dispute Settlement: Public Consultation: 16 May-9 July 2012, 16 (2012).

${ }^{3}$ Jeremy Caddel \& Nathan M. Jensen, Which host country government actors are most often involved in disputes with foreign investors?, COLUM. FDI Perspectives No. 120 (2014).

${ }^{4}$ Christian Tietje \& Freya Baetens, The Impact of Investor-State Dispute Settlement (ISDS) in the Transatlantic Trade and Investment Partnership, para. 83 (2014). 
rules have existed for over fifty years and there has always been disagreement as to whether these rules are in effect shared by developed and developing countries alike. Even though investment treaties are usually bilateral, their level of coherence in terms of "underlying shared substantive principles" is significant: virtually all international investment agreements contain a similar core of protection clauses on expropriation, fair and equitable treatment (FET), full protection and security (FPS), nondiscrimination, and transfer of funds. ${ }^{5}$ Both WTO and ICSID dispute settlement systems have only really taken off since the mid-1990s. Consent to ISDS is in nearly all cases based on a treaty — as cases in which there is a pre-existing specific "contractual/commercial agreement to arbitrate" between the investor and the host state are relatively few. ${ }^{6}$

\section{Different Nomination Incentives_but a Different Planet?}

Pauwelyn identifies six criteria that distinguish ICSID arbitrators from WTO trade adjudicators-focusing on differences in nomination incentives, rather than in perception. First, ICSID arbitrators tend to be of EuroAmerican nationality while many WTO adjudicators have a developing country background (although there has never been an Appellate Body (AB) panel without at least one EU or U.S. member). However, this difference partially results from the interpretation of "nationality": under the WTO system, the European Union is counted as "One nationality-group" excluding EU panelists in disputes involving an EU member; in the ICSID system, EU arbitrators can sit in a case involving a party from another EU member state. If ICSID were to apply the same nationality-definition as the WTO, the number of developing country arbitrators would likely rise as well.

Second, ICSID arbitrators usually come from the private sector and/or academia as opposed to the government officials who very often serve as panelists at the WTO. In this regard, one wonders how Pauwelyn arrives at rather different numbers than Johannesson and Mavroidis, who conducted a similar exercise. ${ }^{7}$ While the statistics for panelists from academia are about the same (18 percent in Pauwelyn's count versus 15 percent in Johannesson \& Mavroidis'); the latter find almost twice as many W'TO panelists from the private sector (25 percent versus Pauwelyn's 15 percent) and substantially fewer WTO panelists in government service (74 percent versus Pauwelyn's 88 percent). For AB members, Pauwelyn counts 72 percent government officials, whereas Johannesson \& Mavroidis detect less than 60 percent.

The third criterion is legal expertise: required under ICSID but optional under the WTO. A law degree is not mandatory under ISDS, but parties consistently choose to nominate arbitrators with a law degree. The WTO rules for panelists only require that they be "well-qualified" but for $\mathrm{AB}$ members, the requirement is that they possess "demonstrated expertise in law, international trade and the subject matter of the covered agreements generally" and it is hard to see how someone could fulfil this condition without a law degree. Pauwelyn states that only 56 percent of WTO panelists and 88 percent of AB Members have law degrees. Johannesson \& Mavroidis, however, state that for 33 percent of all panelists no personal data were disclosed, so they issue a strong caveat with regard to any assertions based on educational background. ${ }^{8}$ Moreover, are the "legal credentials of a diplomat or government official with a decades-old law degree" indeed "likely to be lower than those of an active law professor, serving or former judge, or practicing attorney"'? A diplomat or government official who has been negotiating trade agreements for decades, most likely has as good an understanding as a professor

\footnotetext{
${ }^{5}$ E.g., Jeswald. W. Salacuse, The Emerging Global Regime for Investment, 51 HARV. INT'L L.J., 427, 432 (2010).

${ }^{6}$ E.g., 17,3\% of ICSID cases: ICSID, The ICSID Caseload - Statistics (Issue 2016-1) (2016).

${ }^{7}$ Louise Johannesson \& Petros C. Mavroidis, Black Cat, White Cat: The Identity of WTO Judges, 49 J. WorLD Trade 49685 (2015).

${ }^{8} \underline{I d}$. at 688 .

9 Pauwelyn, supra note 1 , at 774.
} 
who has written scholarly articles about the topic, or, judges/attorneys who spent most of their career adjudicating/practicing other legal matters.

Fourth, the higher diversity of WTO panelists versus ICSID arbitrators is indeed apparent in the relative proportions of panelists from developing countries and women - although a cynic might remark that the less prestigious a job is, the more likely it is that women and non-Westerners do it (particularly if the real power lies in the hands of the Secretariat). The reappointment rate is clearly higher in the ICSID system as compared to the WTO, although neither the ICSID nor the WTO rules contain instructions as to reappointment of adjudicators. Since the proposals for WTO panelists take place behind closed doors, it is not known whether reappointment of panelists is tried more often but rebuffed by the nominees. Closed and elitist networks are omnipresent in both systems - how else would one describe a system in which nearly two out of every three adjudicators was at some point a Geneva-based diplomat?

Fifth, Pauwelyn sketches a sad picture of WTO panelists ("favored candidates with non-controversial positions and those who had been careful in the past not to make enemies in Geneva") and AB members (one successful candidate is reported to have said that "if you want to become [an AB member], I would advise against writing on the subject matter.") ${ }^{10}$ —illustrative of the political rather than legal aspect of appointments. Similar statements have also been made by ICSID arbitrators. If panelists are appointed because they are "mostly technocrats or political appointees operating in large bureaucracies, where team play and policy, rather than individualism and honed legal skills, are valued," 11 this could imply that willingness to arrive at the politically most desired (as opposed to the legally most correct) interpretation is valued more highly. The question is: to what extent is such a system still judicial dispute settlement, as opposed to an intricate form of diplomatic negotiations by way of an intermediary?

The sixth criterion is ideology: ICSID arbitrators are partisan while WTO adjudicators are not. To the extent that the quality (investor or state) of the party that most frequently appoints a particular arbitrator translates into a likelihood that that arbitrator will vote in favor of that party, this is perhaps the single most undermining factor of the public trust in the ISDS system. This should not surprise us: judges at the International Court of Justice, for example, are also most likely to vote in favor of states that have appointed them. ${ }^{12}$ Such conduct does not necessarily indicate bias, it may simply signify a deeper understanding of a party's view—but it certainly risks giving the impression of bias, and thereby cause a lack of trust. A similar problem is unlikely to arise in the W'TO system because all parties involved are states and reappointments do not occur sufficiently frequently to allow particular panelists to build up a reputation in favor of one (kind of) state.

Once the Differences Between WTO Adjudicators and ICSID Arbitrators Have Been Rationalized—Do They Still Exist?

\section{Appointment rules and conditions: theory, practice, and confusion}

While it is correct that, in ISDS, "[e]ach party has an incentive to appoint an arbitrator with a proven track record, outlook, and experience that enhance its chances to prevail in the dispute," is it not slightly simplistic to think that WTO Members are less interested in winning their dispute and consistently more "motivated by broader systemic interests" such as diversifying the pool of adjudicators?13 The number of panels composed by the WTO Director-General (DG) has steadily increased. Although the DG's powers go beyond those of the ICSID Secretary-General, in that the DG is not restricted to the indicative list when proposing a panelist,

${ }^{10} \underline{I d}$. at $779-780$.

${ }^{11} \underline{I d}$. at 781 .

12 Eric A. Posner \& Miguel F. P. de Figueiredo, Is the International Court of Justice biased?, 34 J. LEGAL STUD. 599 (2005).

13 Pauwelyn, supra note 1 , at 787. 
practice indicates that parties wish to preserve some measure of autonomy. First, the right to object has been extensively used-due to a broad interpretation of "compelling reasons." Secondly, reports of panels composed by the DG are twice as likely to be appealed—possibly because parties regard them as less acceptable. ${ }^{14}$

Many ICSID appointments are made unilaterally by investor-claimants which explains why the appointed arbitrators do not have a government background: parties, whether private or public, to a dispute, whether national or international, often wish to be judged by their peers—so private claimants will most likely search for nongovernment affiliated arbitrators. It would have been interesting to see whether respondent states in ISDS cases are any more likely to appoint government officials as arbitrators: one may suspect not (the most frequently reappointed "respondent" arbitrators have not served in government). The recognition of a "desire for peer review" goes a long way to explaining why many WTO panelists have a government background: all parties to WTO disputes are states, and state interests dominate on both sides.

The concept of remuneration as an incentive to adjudicate is absent from the WTO dispute settlement mindset as panelists who are government officials are not paid at all, while others receive a relatively modest per diem. The reality, particularly for panelists from smaller delegations, is that they have to conduct the panel-work on top of their regular duties, which may serve as a perverse incentive in that they might be inclined to spend a minimal amount of time and outsource the work to the Secretariat and/or legal assistants. Senior people and former panelists may refuse to serve again, which may explain the high number of successful appeals and the low reappointment rate. $\mathrm{AB}$ members' remuneration is more generous, by means of a monthly retainer and additional compensation for the actual days worked, resulting in asymmetrical payments as some members serve on more cases than others and/or claim more compensation for work done at home. ${ }^{15}$ The lack of transparency as to who gets paid what makes it difficult to make any sensible comparison between the WTO and ICSID regimes.

\section{Broader institutional context: whither legitimacy?}

Pauwelyn reports that " 68 percent of all panel reports are appealed with the AB modifying or reversing in 84 percent of the appeals" 16: of every one hundred panel reports, sixty-eight are appealed and fifty-seven are modified or reversed, i.e. more than half of the panels overall are considered to have "gotten it wrong"? That is a surprisingly high number, in comparison with appeal statistics of domestic courts ${ }^{17}$ or ICSID annulment statistics: out of 345 concluded cases, there have been eighty-seven (or 20 percent) applications for annulment, which resulted in (partial or full) annulment in 31 percent of filed applications, ${ }^{18}$ or, 6 percent overall. Combined with the fact that a panel ruling is far more likely to be overturned by the $\mathrm{AB}$ when the panel is relatively inexperienced, should this not call into question the WTO appointment procedure?

"Unlike what happens in WTO disputes, there is no institutional memory or collective secretariat input"19 for ISDS as a whole; but ICSID, the Permanent Court of Arbitration and other secretariats provide such input for "their" cases. Many ISDS lawyers start off working for a secretariat, subsequently as a private lawyer or

${ }^{14}$ Reto Malacrida, WTO Panel Composition: Searcbing Far and Wide for Administrators of World Trade Justice, in A HISTORY OF LAW AND LAWYERS IN THE GATTT/WTO 311, 319 n.13 (Gabrielle Marceau ed., 2015).

15 Johannesson \& Mavroidis, supra note 7, at 693.

16 Pauwelyn, supra note 1 , at 794 .

17 A quick search showed that of all appeals filed in civil cases in Scotland, England, and the United States, between 10\% and 20\% succeed so the total number of overturned cases must be well below $10 \%$ as not every first instance decision is appealed against.

${ }^{18}$ Freya Baetens, Keeping the Status Quo or Embarking on a New Course? Setting Aside, Refusal of Enforcement, Annulment and Appeal, in: Reassertion of Control over the InVEstment Treaty Regime (Andreas Kulick ed., forthcoming 2016).

19 Pauwelyn, supra note 1 , at 795. 
academic, and finally are appointed as arbitrators. The epistemic community itself is the collective memory. In the WTO system, most panelists serve only on one panel and have careers confined to government. There is thus no institutional continuity of personnel between the different ad hoc panels- the WTO Secretariat is the only source of continuity.

This raises a number of systemic questions. Should Secretariat officials "make up for the experience or knowledge that panelists lack" 20 ? Does the fact that "many secretariat officials servicing panels are themselves EU/U.S. nationals or have been trained in the EU or United States" 21 not defeat the previously-lauded "representativeness and inclusiveness," if the same limited group of people as lamented in the case of ISDS holds the "real" influence, only in a more hidden way? If the Secretariat is the main driving force, the legitimacy of the panelists cannot be derived from the autonomy of the parties to the dispute (as is the case for ISDS) or from the jointly expressed will of the parties to the treaty (as is the case for the International Court of Justice).

The ISDS system has its own problems with legitimacy, but there is no invisible back-row of adjudicators who are not accountable, whose names are not on the report, whose personal conflicts need not be disclosed, but who may nevertheless exert influence on the decision. After reading Pauwelyn's verdict on the competence of the panel members, one is left with the feeling that, if such a strong Secretariat is needed to counterbalance the weakness of having inexperienced panelists, why not simply appoint stronger panelists and let them, openly, do the job?

\section{Adjudicators Are Neither from Mars or Venus: All Are in the Same Boat}

Very few people will seriously maintain that any adjudicatory panel only executes a "divine, neutral application of the law with no scope for personal direction." 22 The real question is: (why) would it matter that ICSID arbitrators are appointed in response to different incentives than their WTO counterparts? Arguably part of the answer is that each appointment procedure operates logically in accordance with the specific dynamics of its system while the current public perception of each system differs. The latter is variable (one or two controversial W'TO decisions and the perception of the WTO will again be negative) but the former is a systemic difference which can only be addressed by extensive reform of the system, for example, as the European Commission is advocating in its Investment Court System proposal.

Pauwelyn claims that "[w] here adjudicators are less opinionated, less ideologically divided, and more willing to be led by the secretariat, one could predict fewer dissents." ${ }^{23}$ It is quite a leap to conclude that because adjudicators are more likely to understand and support the position that is recognizable to them, they are "opinionated and ideologically divided." More likely, those that have less experience and in-depth knowledge, will be more amenable to being led by a Secretariat - but this hardly contributes to the legitimacy of the adjudicatory system. Studies of other international and regional courts that also found a correlation between the judges' individual background and the likelihood that they will be more supportive of arguments and parties that are familiar to them, only serve to prove that investment arbitrators are not from Mars, WTO adjudicators are not from Venus-all adjudicators are from the same planet, if not actually in the same boat.

\footnotetext{
${ }^{20} \underline{I d}$. at 796 .

${ }^{21} \underline{I d}$.

${ }^{22} \underline{I d}$. at 798.

${ }^{23} \underline{I d}$. at 799 .
} 


\section{Conclusions}

Pauwelyn's paper presents impressive statistical work and raises important issues for further research. One distracting element is that the terms ISDS and ICSID seem to be used interchangeably, while nearly all statistics are based on ICSID data. When discussing "ICSID arbitrators," it is unclear whether this refers to arbitrators appointed under the ICSID Convention (about 57 percent), ${ }^{24}$ or also those under the ICSID Additional Facility Rules (about 63 percent), or those in cases administered by ICSID (about 77 percent). In any case, Pauwelyn's statistics do not seem to cover between 23 percent and 43 percent of arbitrators, meaning that his conclusions are not as representative as they could be. Furthermore, quantification exercises are not an exact science: the conclusions drawn ought to be approached with care as a different calculation method may lead to different, possibly less strong correlations.

Pauwelyn's main conclusion is that

[g]iven the diverse history, goals, and design features of the WTO and ICSID, it should be no surprise that the universe of W'TO adjudicators is different from that of ICSID arbitrators. However, with the increasing convergence of, and forum shopping between, the two systems, these differences have become acutely important. 25

The existence of this "increasing convergence" can be disputed seeing that it seems to be mainly limited to the fact that many countries are currently concluding treaties which contain trade and investment chapters, as opposed to the old practice where free trade agreements and bilateral investment treaties (BITs) were concluded separately. Forum shopping between the two systems stricto sensu is impossible because different rules will be invoked by different parties, but even speaking more broadly (the same facts giving rise to parallel proceedings), this is limited to a handful of cases. It remains to be seen what actual difference in practice this has made or is likely to make in future.

Several other reasons could explain the lack of cross-fertilization between ISDS and WTO case law. For example, ISDS claims are mainly complaints about the implementation of rules; while WTO claims are mostly aimed against the rules themselves. There can be an institutional bias against less-institutionalized forms of dispute settlement (WTO vis-à-vis ISDS) or simply a lack of knowledge (as Pauwelyn writes, some WTO panel members are not even well-versed in the ins and outs of the trade system, let alone would look beyond the borders of the trade field). ISDS awards refer to WTO cases where relevant, but ISDS tribunals search for the violation of treaty obligations by means of individually-extended treatment, while WTO panels look at aggregate effects. Many of the common substantive rules in ISDS are entirely absent in WTO law (FET, FPS, expropriation); while the WTO system contains a specific set of necessity-based exceptions which are not included in most investment agreements. Interpreting the lex specialis of Article XX of the General Agreement on Tariffs and Trade is not helped much by reference to the general necessity clause in the Argentina-U.S. BIT.

Pauwelyn argues that Weiler's prediction-that WTO dispute settlement was destined to legalize further and to move away from its "diplomatic ethos" in order to gain more "external legitimation" — has not, or only partly, materialized. But the WTO has managed to maintain much of its diplomatic ethos, as exemplified by the significant majority of Geneva-insiders appointed as panelists, at the cost of its external legitimacy. It may well be that

a relatively ad hoc, party-driven mechanism to settle disputes under the cautious control of government members, based on lengthy, often impenetrable rulings that only insiders can understand and where

${ }^{24}$ Investment Policy Hub, Arbitral rules and administering institution, UNCTAD.

${ }^{25}$ Pauwelyn, supra note 1 , at 799. 
politically sensitive cases against big players result in diplomatic, give-and-take settlements with trade or cash compensations rather than rule compliance ${ }^{26}$

works, but this is arguably a regrettable state of affairs from a legal point of view. If the goal of adjudication is to move from a system where "might is right" towards a "rule of law," then the current WTO system to some extent has failed.

WTO dispute settlement has indeed "spawned a sophisticated and well-respected jurisprudence"27 (although the level of support may vary greatly from case to case, and from Member to Member) - which is arguably in spite of the predominance of diplomats, and due to the presence of high-powered, elite jurists with a high level of expertise on the $\mathrm{AB}$ bench. It is unsurprising that $\mathrm{AB}$ members have also been appointed as ISDS arbitrators. Arguably, the mere existence of an ISDS appeal mechanism could facilitate some necessary changes in terms of diversity, openness, and inclusion as it could be a game changer for first instance appointments. Parties would probably be much more willing to appoint others than the usual "star arbitrators," if they know they have a second chance on appeal.

A reform of the W'TO panel system and the creation of an ISDS appellate mechanism, bearing in mind the different dynamics of interstate versus individual-state dispute settlement and ensuring transparency, will go far towards changing unfavorable perceptions and allow both adjudicatory systems to focus on their true purpose, to paraphrase Weiler: "the pursuit of justice within the oft elusive rule of law."28

${ }^{26} \underline{I d}$. at 802 .

$27 \underline{I d}$. at 763 .

${ }^{28}$ J.H.H. Weiler, The Rule of Lawyers and the Ethos of Diplomats: Reflections on the Internal and External Legitimacy of WTO Dispute Settlement, 35 J. WORLD TRADE 191, 207 (2001). 